\title{
Evaluation of cultivars and land races of Oryza sativa for restoring and maintaining wild abortive cytoplasm
}

\author{
Bal KJ oshi†*, Laxmi P Subedił, Santa B Gurung: and Ram C Sharma \\ $\uparrow$ Agricultural Botany Division, Nepal Agricultural Research Council (NARC), Lalitpur, PO Box 1135, Nepal \\ \$Instituteof Agricultureand Animal Science, Tribhuvan University, Rampur, Chitwan, Nepal \\ * Towhom correspondenceshould beaddressed.E-mail:joshibalak@rediffmail.com
}

Identification of restorers and maintainers from cultivars and landraces through test crossing and their use in further breeding programme are the initial steps in three-line heterosis breeding. Two experiments, one in the greenhouse for $F_{1}$ hybrid seeds production and another in the field for parental screening, were conducted during the 1999 rice growing season at the Institute of Agriculture and Animal Science (IAAS, TU), Rampur, Nepal. Three cytoplasmic male sterile (CMS) lines, eight improved cultivars and six landraces of rice were studied for their fertility restoring and sterility maintaining abilities. Pollen sterility was studied based on their stainability with potassium iodide iodine (I-KI) solution. On the basis of their interaction with I-KI, pollens were categorized as unstained withered sterile (UWS), unstained spherical sterile (USS), stained round sterile (SRS) and stained round fertile (SRF). For each hybrid, the percentage of spikelet fertility was estimated. The test lines were categorized as restorers, partial restorers, maintainers, and partial maintainers on the basis of pollen sterility and spikelet fertility. The male sterile lines had mostly UWS and USS types of pollen, whereas the restorer lines had more SRS and SRF types. There was no strong evidence for a relationship between pollen fertility and spikelet fertility. Five restorers, three partial restorers, two partial maintainers and four maintainers were identified. These restorers can be used to develop the hybrid seed while maintainers to maintain and/or to develop new CMS lines, because these are locally adapted cultivars. Pedigree analysis revealed that, for some of these test lines, TN-1 and CR94-13 might be the donors of maintainer and restorer gene(s), respectively.

Key words: CMSline, maintainer, restorer, rice

Him J Sci 1(2): 87-91

Received: 9 Feb 2003

URL: www.himjsci.com/issue2/oryzasativa

Accepted after revision: 15 Apr 2003

\section{Introduction}

In Nepal, riceaccountsfor about $50 \%$ of thetotal cropped area and food production (Upadhaya 1996). Efforts to improve rice productivity in Nepal have resulted in the introduction of a large number of improved cultivars with varyingyield potentials. To meet the demand created by increasing population and rising incomes, it is important to increase the yield potential of ricebeyond that of semi-dwarf cultivars. Experiences in China, India, andVietnam have established that hybrid riceoffers an economically viableoption to increase cultivar yield. The usual method for raising hybrids is to establish many inbred lines, perform inter-crosses and determine which hybridsaremost productivein a given locality. Asthefemale parents haveto bemalesterile, they should bemaintained in every generation and malesterilelines haveto bedeveloped. They should belocally adapted and should perform well in hybrid combinations. The basic requisites for successful hybrid rice production are development of malesterilelines (A), maintainers (B) and restorers of fertility (R). Lin and Yuan (1980) reported the use of an effective restorer in Chinain commercial $F_{1}$ hybrids involvingthewild aborted (WA) cytosterility system in 1973. Effective restorer lines for WA, Gam and Bt cytosterility systems have been identified among cultivated ricecultivarsand elite breedinglines(Shinjyo 1969, 1972, Lin and Yuan 1980). For the CMS-WA system hundreds of effective restorer lines have been identified among cultivated rice cultivars and elitebreedinglines bred in China (Lin andYuan 1980, Yuan etal. 1994), International Rice Research Institute (IRRI 1983, Govinda Raj and Virmani 1988, Virmani 1994), Indonesia (Suprihatno et al.
1994), India (Rangaswamy et al. 1987, Siddiq et al. 1994), and the Philippines (Lara et al. 1994). The restorer lines for WA cytosterility were found more stable and their restoration ability was stronger (Virmani 1996). The frequency of restorer lines was higher among latematuring Indica cultivarsand negligibleamongJaponicacultivars (Lin and Yuan 1980). The varieties IR24, IR26, IR661 and IR665, restorer of the most widely cultivated hybrids in China were developed at the IRRI (Virmani and Edwards 1983).

Identification of maintainers and restorers from elite breeding lines and landraces through test crossing (Ikehashi and Araki 1984, Virmani 1996) and their use in further breeding programme are the initial steps in three-line heterosis breeding (Siddiq 1996). Theobjectives of thisstudy therefore, wereto identify rice landraces and cultivars with fertility restoring ability and to identify maintainers of sterility among the test lines.

\section{Materials and methods}

Plant materials

Thisexperiment wasconducted in a greenhouseand experimental farm at the Institute of Agriculture and Animal Sciences (IAAS), Tribhuvan University, Rampur, Chitwan, Nepal, during the dry and wet seasons of 1999. The IAAS is located at 84²9' E and 27ㅇ 37' $\mathrm{N}(224 \mathrm{~m}$ asl). Details of the 9 improved cultivars, 6 landracesand 3 wild aborted cytoplasmic male sterile (CMS) lines of rice used in thisstudyaregiven in Tablel Theimproved cultivarsand landraces were obtained from the National Rice Research Program (NRRP), Hardinath, and IAAS, Rampur, respectively. The CMS lines were 


\section{RESEARCH PAPERS}

obtained from the IRRI, Philippines.

$F_{1}$ seeds production

Crossing was performed in a greenhouse, using cylindrical crossing chambers made of $2.5 \mathrm{~m}$ plastic sheet. The top portion of the chamber was open. The pollen parents wereseeded threetimes to ensure a continuous supply of pollen to the female parent during theperiod of flowering, whiletheCMSlines were seeded only once. Beforecrossing, each CMSplant wastested for pollen sterility. This was determined by staining pollen grains in $1 \%$ potassium iodideiodine (I-KI) solution. At heading, about 10 spikelets from each plant were collected in the morning just prior to blooming and fixed in $70 \%$ alcohol. All the anthers from 6 spikelets were excised with the help of forceps and placed in the stain. The pollen grains were released with a needle and gently crushed. After the debris was removed, a cover slip was placed over the pollen material and it was observed under a microscope(10x). Themethod issimilar to that described byVirmani et al. (1997) and Chaudhary et al. (1981). TheCMSplants showing completesterility were used for crossing. The $F_{1}$ seeds were produced in thegreenhouse using theApproach method (Erickson 1970).

\section{Screen nursery}

A field experiment involving $14 \mathrm{~F}_{1}{ }_{1} \mathrm{~s}, 14$ pollen parents, and $3 \mathrm{CMS}$ lines was conducted to screen the cultivars/landraces. The block wasdivided into 31 plots of $0.8 \mathrm{~m}^{2}$ sizeeach. The pollen parent was

TABLE 1. Improved rice cultivars, landraces and CMS lines used in this study

\begin{tabular}{|c|c|c|c|c|c|c|}
\hline \multicolumn{7}{|c|}{ A. Improved cultivars } \\
\hline \multirow[t]{2}{*}{ Cultivar } & \multirow[t]{2}{*}{ Pedigree } & \multirow[t]{2}{*}{ Parentage } & \multirow[t]{2}{*}{ Origin } & \multirow[t]{2}{*}{ Grain type } & \multicolumn{2}{|c|}{$\begin{array}{l}\text { Reaction to } \\
\text { diseases }\end{array}$} \\
\hline & & & & & Bl & BB \\
\hline Bindeswari & IET1444 & TN1/Co29 & India & Medium & MR & MS \\
\hline Chaite-6 & $\begin{array}{l}\text { NR274-7-3- } \\
3-1\end{array}$ & NR6-5-46-50/IR28 & Nepal & Medium & $\mathrm{R}$ & $\mathrm{R}$ \\
\hline Janaki & BG90-2 & Peta*3/TN1//Remadja & Sri Lanka & Coarse & $\mathrm{R}$ & MR \\
\hline Sabitri & $\begin{array}{l}\text { IR2071-124 } \\
6-4\end{array}$ & IR 1561/IR1737// CR94-13 & IRRI & Coarse & MR & MR \\
\hline Radha-11 & TCA80-4 & Local selection & India & Medium & $S$ & MR \\
\hline Kanchan & $\begin{array}{l}\text { IR39341- } \\
\text { 4PL-P28 }\end{array}$ & CR 126-42-5/IR 2061-213 & IRRI & Medium & MR & - \\
\hline Khumal-4 & $\begin{array}{l}\text { NR10078- } \\
76-1-1\end{array}$ & IR 28/Pokhreli Masino & Nepal & Fine & $\mathrm{R}$ & - \\
\hline Khumal-7 & $\begin{array}{l}\text { IR7167-33- } \\
\text { 2-3-3-1 }\end{array}$ & $\begin{array}{l}\text { China1039DWF-MUT/Kn-1B- } \\
\text { 361-1-8-6-10 }\end{array}$ & IRRI & Coarse & $\mathrm{R}$ & - \\
\hline
\end{tabular}

Bl-Blast, BB-Bacterial blight, MR- Moderately resistant, M- Moderately susceptible, R-Resistant, S- Susceptible

Source: NRRP 1997

B. Landraces

\begin{tabular}{lll}
\hline Landrace & Origin & Remarks \\
\hline Deharadune & Nepal & All landraces are popular local cultivars of hilly area of Nepal and have \\
Ratodhan & Nepal & intermediate stature. They matureearlier than local cultivars of the Tarai \\
and arefield resistant to blast and bacterial leaf blight \\
Kature & Nepal & \\
Chiunde & Nepal & \\
IAR-97-34 & Nepal & \\
\hline
\end{tabular}

C. CMS lines of wild aborted type

\begin{tabular}{llll}
\hline CMSline & Origin & Parentage & Remarks \\
\hline IR58025A & IRRI & IR4843A/8*Pusa167-120 & $\begin{array}{l}\text { Stable in sterility, best combiner for yield, has aromatic long } \\
\text { slender grains; using this linemorethan 50 hybrids have } \\
\text { been devel oped in India. }\end{array}$ \\
\hline IR62829A & IRRI & IR46828A/8*IR29744-94 & $\begin{array}{l}\text { Stable in sterility, has functional male sterility, very good } \\
\text { combiner; using this line morethan 20 hybridshavebeen } \\
\text { developed in India. }\end{array}$ \\
\hline IR68888A & IRRI & $\begin{array}{l}\text { IR62829A/6*IR62844 } \\
\text { 15//IR629744-94 }\end{array}$ & Stable in sterility, good combiner \\
\hline
\end{tabular}

Source: DRR 1996 
planted beside their $\mathrm{F}_{1}$ and $\mathrm{CMS}$ planted after the pollen parent. The field was fertilized at the rate of $120 \mathrm{~kg} \mathrm{~N}, 60 \mathrm{kgP}_{2} \mathrm{O}_{5}$ and $60 \mathrm{~kg}$ $\mathrm{K}_{2} \mathrm{O}$ per ha. Half of thenitrogen was applied as a basal doseand half top-dressed onemonth after transplanting. The21-day-old seedlings were transplanted in the field in two rows with 10 hills per row at spacing of $20 \mathrm{~cm}$ between rows and $20 \mathrm{~cm}$ between plants. Asingle seedling was planted in each hill. Pollen and spikelet fertility were measured from each plot.

Pollen sterility

Pollen sterility of the $F_{1} s$ was determined by staining pollen grains in 1\% I-KI solution (Dalmacio et al. 1995, Virmani et al. 1997, Chaudharyet al. 1981, Sohu and Phul 1995, Young et al. 1983). The pollen grains in 3 randomly selected microscopic fields were counted. The pollen grains were classified based on their shape, size and extent of staining (Virmani et al. 1997, Young et al. 1983, Chaudhary et al. 1981) as shown in Box 1

In thecase ofCMSlines and somehybrids, thepatterns of pollen abortion were classified as follows (Chaudhary et al. 1981):

Type 1: Almost all pollen grains appear as UWS and USS.

Type2:Themajority of pollen grainsappear asUSS(51\%), followed by SRS (36\%) and UWS (14\%).

Type 3: Themajority of pollen grainsareSRS(52\%); UWS and USS are $20-25 \%$

Spikelet fertility

Five panicles from each experimental unit were bagged before floweringfor spikelet fertility analysis. At maturity, thebagged panicles were examined for seed set. Spikelet fertility was determined by dividingthetotal number of seedsby thetotal number of spikelets. Test lines were classified on the basis of pollen fertility and spikelet fertility (Table 2).

$\mathrm{F}_{1} \mathrm{~s}$ were also classified on the basis of seed set as male parent or weaker than male parent, anthers whether plumpy yellow or white shriveled.

\section{Results and discussion}

The pollen and spikelet fertility of hybrids are given in Table 3 . In hybrids, pollen fertility ranged from 1 to $82 \%$ and spikelet fertility varied from 0 to $87 \%$. Pollen fertility varied from 28 to $97 \%$, while spikelet fertility ranged from 73 to $91 \%$ in pollen parents (Table4). Our data indicates that pollen's susceptibility to staining with I-KI solution does not correlatewith spikelet fertility. Thismay be due to the ability of single fertile pollen to fertilize a spikelet. It

BOX 1. Categories of rice pollen and their features

\begin{tabular}{lll}
\hline $\begin{array}{l}\text { Category of } \\
\text { pollen }\end{array}$ & $\begin{array}{l}\text { Shapeand } \\
\text { stainingbehaviour }\end{array}$ & Classification \\
\hline $\begin{array}{l}\text { Unstained withered } \\
\text { sterile(UWS) }\end{array}$ & $\begin{array}{l}\text { Withered and } \\
\text { undevel oped, } \\
\text { unstained }\end{array}$ & Sterile \\
\hline $\begin{array}{l}\text { Unstained spherical } \\
\text { sterile(USS) }\end{array}$ & $\begin{array}{l}\text { Spherical and smaller, } \\
\text { unstained }\end{array}$ & Sterile \\
\hline $\begin{array}{l}\text { Stained round sterile } \\
\text { (SRS) }\end{array}$ & $\begin{array}{l}\text { Round and small, } \\
\text { lightlyor incompletely } \\
\text { stained, rough } \\
\text { surface }\end{array}$ & Sterile \\
\hline $\begin{array}{l}\text { Stained round fertile } \\
\text { (SRF) }\end{array}$ & $\begin{array}{l}\text { Round and large, darkly } \\
\text { stained, smooth surface }\end{array}$ & Fertile \\
\hline
\end{tabular}

TABLE 2. Classification of test lines into maintainers and restorers

\begin{tabular}{lll}
\hline Pollen fertility(\%) & Category & Spikeletfertility(\%) \\
\hline $0-1$ & Maintainer & 0 \\
\hline $1.1-50$ & Partial maintainer & $0.1-50$ \\
\hline $50.1-80$ & Partial restorer & $50.1-75$ \\
\hline 80 & Restorer & $>75$ \\
\hline
\end{tabular}

Source:Virmani etal.1997

TABLE 3. Pollen and spikelet fertility of hybrids

\begin{tabular}{|c|c|c|c|c|c|c|c|}
\hline SN & Hybrid & $\begin{array}{l}\text { Pollen fertility } \\
\text { (\%) }\end{array}$ & $\begin{array}{l}\text { Spikelet } \\
\text { fertility (\%) }\end{array}$ & Seed setas & F/S & Testline & $\begin{array}{l}\text { Inference on } \\
\text { testline }\end{array}$ \\
\hline 1 & IR68888A/Radha-11 & 80 & 87 & MP & $\mathrm{F}$ & Radha-11 & $\mathrm{R}$ \\
\hline 2 & IR58025A/Janaki & 49 & 33 & W & $\mathrm{F}$ & Janaki & PM \\
\hline 3 & IR58025A/Kanchan & 81 & 75 & MP & $\mathrm{F}$ & Kanchan & $\mathrm{R}$ \\
\hline 4 & IR58025A/Khumal-4 & 32 & 57 & MP & $\mathrm{F}$ & Khumal-4 & PR \\
\hline 5 & IR58025A/ Sabitri & 82 & 84 & MP & $\mathrm{F}$ & Sabitri & $\mathrm{R}$ \\
\hline 6 & IR58025A/Chaite-6 & 55 & 58 & W & $\mathrm{F}$ & Chaite-6 & PR \\
\hline 7 & IR68888A/Bindeswari & 1 & 0 & W & $\mathrm{F}$ & Bindeswari & $M$ \\
\hline 8 & IR68888A/Khumal-7 & 1 & 0 & W & $\mathrm{S}$ & Khumal-7 & $M$ \\
\hline 9 & IR62829A/Deharadune & 1 & 0 & W & $\mathrm{F}$ & Deharadune & $M$ \\
\hline 10 & IR62829A/Ratodhan & 82 & 79 & MP & $\mathrm{F}$ & Ratodhan & $\mathrm{R}$ \\
\hline 11 & IR68888A/Gogi & 59 & 26 & W & $\mathrm{F}$ & Gogi & PM \\
\hline 12 & IR62829A/Kature & 81 & 76 & MP & $\mathrm{F}$ & Kature & $\mathrm{R}$ \\
\hline 13 & IR68888A/Chiunde & 1 & 0 & W & $\mathrm{F}$ & Chiunde & $M$ \\
\hline \multirow[t]{4}{*}{14} & IR58025A/IAR-97-34 & 56 & 49 & MP & $\mathrm{F}$ & IAR-97-34 & PR \\
\hline & Range & $1-82$ & $0-87$ & & & & \\
\hline & Mean & 47 & 45 & & & & \\
\hline & SE & 9.04 & 9.15 & & & & \\
\hline
\end{tabular}

MP-maleparent, W-weaker than MP, F-plumpyyellow anthers, S-whiteshriveled anthers on visual basis, R-restorer, PR-partial restorer,

$\mathrm{PM}$-partial maintainer, M-maintainer 
suggests that pollen fertility is independent of the spikelet fertility. Thereforeeven a low number of fertile pollen counted in thisstudy can givea higher seed set. However, thesterility of theinter-varietal ricehybridsisdueprimarily to pollen sterility. Guiquen etal. (1994) reported that sterility in theinter-varietal hybrids of cultivated rice is caused by the allelic interaction at the $F_{1}$ pollen sterility loci. Six loci of genes controlling $\mathrm{F}_{1}$ pollen sterility in ricehave been reported (Guiquen etal. 1994). Ourstudy is in agreement with Guiquen etal. (1994) in that among $F_{1}$ hybrids, the higher the incidence of the heterozygote $\mathrm{S} / \mathrm{S}$ at the six loci, the higher the incidence of pollen sterilityand spikelet sterility.

Three CMS lines had a higher percentage of UWS and USS than that of rest lines. IR68888A had no SRF at all while the other two had somefertile pollen (Table4). The higher percentage of SRS in hybrids IR68888A/Bindeswari, IR68888A/Khumal-7, IR62829A/Deharaduneand IR68888A/Chiundewasassociated, on average, with $1 \%$ SRF. Thehybridshavinghigher SRSwereassociated with high frequency of SRF as in IR68888A/ Radha-11, IR58025A/ Janaki, IR58025A/Kanchan, IR58025A/ Khumal-4, IR58025A/Sabitri, IR58025A/Chaite-6, IR62829A/Ratodhan, IR62829A/Kature and IR58025A/IAR-97-34. Table 4 shows that hybrids with some SRF pollen had fewer filled grainsin thepanicles. Itindicates that hybrids having higher UWSand USS will bemore useful for developingnew CMSlines from their sterile hybrids.

The hybrids were classified as semi-sterileon the basis of spikelet fertility of $40-80 \%$. The male parents of thesehybrids were designated as partial restorers. In thesehybrids, SRShad dominated the other pollen categories. The partial restorer IAR-97-34 had

TABLE 4. Pollen categories and types of male sterility in male sterile lines, hybrids and test lines

\begin{tabular}{|c|c|c|c|c|c|c|c|c|c|}
\hline \multirow[t]{2}{*}{ SN } & \multirow[t]{2}{*}{ CMS/ hybrid/testline } & \multirow{2}{*}{$\begin{array}{l}\text { Total pollen } \\
\text { examined }\end{array}$} & \multicolumn{4}{|c|}{ Frequency (\%) } & \multirow[t]{2}{*}{ Type } & \multirow{2}{*}{$\begin{array}{l}\text { Pollen } \\
\text { sterility (\%) }\end{array}$} & \multirow{2}{*}{$\begin{array}{l}\text { Spikelet } \\
\text { fertility (\%) }\end{array}$} \\
\hline & & & UWS & USS & SRS & SRF & & & \\
\hline 1 & IR68888A & 238 & 47.27 & 50.77 & 1.96 & 0.00 & 1 & 100.00 & 0.00 \\
\hline 2 & IR58025A & 385 & 29.67 & 68.25 & 0.69 & 1.38 & 1 & 98.62 & 0.00 \\
\hline 3 & IR62829A & 268 & 27.77 & 38.85 & 21.67 & 11.70 & I & 88.30 & 0.00 \\
\hline 4 & IR68888A/Radha-11 & 455 & 4.94 & 5.49 & 31.14 & 58.43 & & 41.57 & 86.82 \\
\hline 5 & Radha-11 & 493 & 0.14 & 1.49 & 24.36 & 74.02 & & 25.98 & 83.96 \\
\hline 6 & IR58025A/Janaki & 374 & 12.13 & 18.11 & 20.79 & 48.97 & & 51.03 & 32.98 \\
\hline 7 & Janaki & 521 & 3.78 & 2.18 & 14.08 & 79.96 & & 20.04 & 75.34 \\
\hline 8 & IR58025A/Kanchan & 426 & 2.35 & 4.77 & 27.91 & 64.97 & & 35.03 & 75.00 \\
\hline 9 & Kanchan & 427 & 0.86 & 0.86 & 14.74 & 83.54 & & 16.46 & 73.13 \\
\hline 10 & IR58025A/Khumal-4 & 289 & 3.92 & 15.11 & 51.10 & 29.87 & III & 70.13 & 57.27 \\
\hline 11 & Khumal-4 & 553 & 0.00 & 0.00 & 20.51 & 79.26 & & 20.74 & 88.92 \\
\hline 12 & IR58025A/Sabitri & 440 & 1.29 & 7.65 & 21.05 & 70.02 & & 29.98 & 84.43 \\
\hline 13 & Sabitri & 587 & 0.57 & 2.44 & 29.51 & 67.48 & & 32.52 & 86.34 \\
\hline 14 & IR58025A/Chaite-6 & 304 & 4.93 & 8.88 & 31.36 & 54.83 & & 45.17 & 57.54 \\
\hline 15 & Chaite-6 & 283 & 1.18 & 0.71 & 3.53 & 94.59 & & 5.41 & 86.02 \\
\hline 16 & IR68888A/Bindeswari & 288 & 12.49 & 38.27 & 48.25 & 1.00 & III & 99.00 & 0.00 \\
\hline 17 & Bindeswari & 468 & 0.00 & 2.99 & 0.36 & 96.66 & & 3.34 & 82.94 \\
\hline 18 & Masuli (check) & 266 & 0.63 & 16.44 & 54.96 & 27.98 & III & 72.02 & 84.23 \\
\hline 19 & IR68888A/Khumal-7 & 193 & 10.02 & 28.67 & 60.32 & 1.00 & III & 99.00 & 0.00 \\
\hline 20 & Khumal-7 & 457 & 0.22 & 1.31 & 21.79 & 76.68 & & 23.32 & 79.26 \\
\hline 21 & IR62829A/Deharadune & 401 & 4.91 & 21.36 & 73.15 & 1.00 & III & 99.00 & 0.00 \\
\hline 22 & Deharadune & 338 & 4.14 & 17.24 & 9.07 & 69.56 & & 30.44 & 81.84 \\
\hline 23 & IR62829A/Ratodhan & 462 & 0.22 & 2.74 & 19.48 & 77.56 & & 22.44 & 78.73 \\
\hline 24 & Ratodhan & 455 & 0.37 & 3.59 & 12.68 & 83.36 & & 16.64 & 78.15 \\
\hline 25 & IR68888A/Gogi & 394 & 4.82 & 22.51 & 13.96 & 58.71 & & 41.29 & 26.15 \\
\hline 26 & Gogi & 440 & 0.30 & 2.20 & 16.00 & 81.50 & & 18.50 & 66.99 \\
\hline 27 & IR62829A/Kature & 352 & 7.76 & 10.89 & 25.00 & 56.34 & & 43.66 & 76.00 \\
\hline 28 & Kature & 547 & 0.43 & 4.20 & 32.66 & 62.71 & & 37.29 & 87.45 \\
\hline 29 & IR68888A/Chiunde & 228 & 26.28 & 48.18 & 25.50 & 0.50 & II & 99.50 & 0.00 \\
\hline 30 & Chiunde & 403 & 0.99 & 12.33 & 31.02 & 55.67 & & 44.33 & 73.45 \\
\hline 31 & IR58025A/IAR-97-34 & 451 & 6.35 & 13.52 & 23.71 & 56.43 & & 43.57 & 49.34 \\
\hline \multirow[t]{4}{*}{32} & IAR-97-34 & 496 & 0.60 & 6.51 & 25.52 & 67.36 & & 32.64 & 90.56 \\
\hline & Range & $193-587$ & $0-47.27$ & $0-68.25$ & $0.36-73.15$ & $0-96.66$ & & $3.34-100$ & $0-90.56$ \\
\hline & Mean & 396.31 & 6.92 & 14.95 & 25.25 & 52.9 & & 47.09 & 57.59 \\
\hline & SE & 18.12 & 1.93 & 3.01 & 3.01 & 5.48 & & 5.49 & 6.07 \\
\hline
\end{tabular}

UWS, unstained withered sterile, USS, unstained spherical sterile, SRS, stained round sterile, SRF, stained round fertile, Type I- almost all pollen appears as UWS and USS, II-majority of pollen as USS (51\%) followed by SRS (36\%) and UWS (14\%), III-majority of pollen SRS followed by USS and UWS 
TABLE 5. Restorers and maintainers for three CMS lines

\begin{tabular}{lll}
\hline CMSline & Restorers & Maintainers \\
\hline IR58025A & Kanchan, Sabitri & - \\
\hline IR62829A & Kature, Ratodhan & Deharadhune \\
\hline IR68888A & Radha-11 & $\begin{array}{l}\text { Bindeswori, } \\
\text { Khumal-7, Chiunde }\end{array}$ \\
\hline Frequency(\%) & 36 & 29 \\
\hline
\end{tabular}

morespikelet sterility than theother two partial restorers, Khumal4 and Chaite-6. Spikelet fertility percentage varied widely among hybrids, and many hybrids had a lower spikelet fertility percentage than the high-yielding cultivars. Therefore, it is of practical importance to understand the causes of high spikelet sterility in hybrids for possible increase in spikelet fertility.

Restorers and maintainers identified in the study are summarized in Table 5. Among these lines, five were restorers, three were partial restorers, four were maintainers and two were partial maintainers. Radha-11 was found to bean effectiverestorer for IR68888A, Kanchan and Sabitri for IR58025A and Ratodhan and Katurefor IR62829A. Bindeswari and Khumal-7 werefound to be maintainers for IR68888A, and Deharadune for IR62829A. No maintainer for IR58025A was found. With respect to maintaining ability, all maintainersappeared to function effectivelyin maintaining sterility. All $\mathrm{F}_{1}$ of these pollen parents with CMS showed a rate of $0 \%$ spikelet fertility and 0.5 to $1 \%$ pollen fertility. The frequency of restorers (36\%) was higher than that of maintainers (21\%). The frequency of restorer lines was higher among rice cultivars originating in lower latitudes. Virmani and Edwards (1983) reported that effectiverestorer cultivarsweremainly distributed in thetropics where Indica rice was exclusively grown. Virmani (1996) found a lower incidence of restorer lines in northern China, eastern Europe, Japan, and Korea. The restoring ability of rice cultivars has been found to be, to some extent, related to their origin (Govinda Raj and Virmani 1988). Among Indica rice cultivars the frequency of $R$ geneishigher in latematuring cultivars than in earlymaturingones (Ahmed 1996). Therestorer frequency is very low in typical Japonica rice cultivars (Lin and Yuan 1980, Virmani et al. 1981). It suggests thatorigin and pedigree of test linesareimportant characters to be considered in evaluating the rice genotypes for restoring and maintainingWA cytoplasm. Maintainer line, Bindeswari had been derived from the Taichun Native 1 (TN-1). Therefore, Bindeswari may have received its maintaining property from $T N-1$. Similarly the restorer gene in Sabitri might have come from CR94-13. Since the restorers and maintainers identified here are locally adapted, thesecultivarsand landraces may havevaluein heterosis breeding. Restorers can be improved (Liu et al. 1998) by using various procedures. Among the approaches used in developing new restorers, recombination breeding is the most common (Ahmed 1996). New restorers can be developed through cross breeding, which can enlarge the genetic base of $R$ lines by pyramiding complementary traits from various sources in order to meet the breedingobjectives. TheCMS-WA system has been used extensively to transfer cytoplasmic male sterility traits in various genotypes both within and outside of China. The intensive use of a single source of malesterilecytoplasm in developing hybrid cultivarswas found disastrous in the cases of Texas cytoplasm in maize and Tift cytoplasm in pear millet (Pokhriyal et al. 1974). It was therefore, considered wise to diversify sources of the cytoplasm. The maintainer and restorer lines identified here may be useful in increasing genetic diversity. The restorers can be used to develop hybrids and the maintainers to maintain and/or to develop new CMSlines.

\section{References}

Ahmed HI. 1996. Outlines of heterosis breeding program in rice. In: Ahmad MI, BC Viraktamath, MSRameshaand CHM VijayaKumar (eds), Hybrid ricetechnology. Hyderabad: ICAR, Directorateof RiceResearch. p 55-65

Chaudhary RC, SSVirmani and GSKhush. 1981. Patterns of pollen abortion in some cytoplasmic-genetic malesterilelines of rice. Oryza 18: 140-2

Dalmacio R, DSBrar, T Ishii, LA Sitch, SSVirmani and GSKhush. 1995. Identification and transfer of a new cytoplasmic male sterility source from Oryza perennis into indicarice(O. sativa). Euphytica 82: 221-5

DRR. 1996. Final report (1991-96): Development and use of hybrid rice technology. Hyderabad: ICAR/UNDP/FAO project, ICAR, Directorateof Rice Research. 87 $\mathrm{p}$

EricksonJR. 1970. Approach crossing of rice. CropSci 10:610-1

Govinda Raj K and SS Virmani. 1988. Genetics of fertility restoration of WA type cytoplasmic male sterility in rice. Crop Sci 28: 787-92

Guiquen Z, LYonggen, ZHau, YJinchangand L Guifu. 1994. Geneticstudieson thehybrid sterility in cultivated rice (Oryza sativa) IV: Genotypes for $F_{1}$ pollen sterility. Chin J Genet 21: 35-42

Ikehashi $\mathrm{H}$ and $\mathrm{H}$ Araki. 1984. Varietal screening of compatibility types revealed in $\mathrm{F}_{1}$ fertility of distant crossed in rice. Jpn J Breed 34: 304-13

IRRI. 1983. Annual report for 1981. Manila: IRRI

LaraRJ, IM DelaCruz, MSAblaza, HCDelaCruzand SRObien. 1994. Hybrid riceresearch in thePhilippines. In:Virmani SS(ed), Hybrid ricetechnology:New developments and future prospects [Selected papers from the International Rice Research Conference]. Manila:IRRI. p 173-86

Lin SC and LPYuan. 1980. Hybrid ricebreedingin China. In: Innovativeapproachesto ricebreeding. Manila:IRRI. p 35-51

Liu XC, SS Virmani and BC Viraktamath. 1998. Improving parental lines to increase efficiency of hybrid rice breeding: Somenew approaches. In:Virmani SS, EA Siddiqand KMuralidharan (eds), Advancesin hybrid ricetechnology. Proceedings of the3rd International Symposium on Hybrid Rice; 1996Nov 14-16; Hyderabad, India. Manila: IRRI. p 99-110

NRRP. 1997. 25years of riceresearch in Nepal (1972-1997). Kathmandu: National Rice Research Programme, NARC. $41 p$

Pokhriyal SC, RR Patil, R Dass and BC Singh. 1974. Combining ability of new male sterile lines in pearl millet. Ind J Genet Plant Breed 34: 208-15

Rangaswamy M, K Natarajamoorthy, GS Palnisamy and SR Sreerangaswamy. 1987. Isolation of restorersand maintainersfor two Chinesemalesterilelineshaving wild abortivecytoplasm. IntRiceResNewsletter 12: 13

Shinjyo C. 1969. Cytoplasmic-genetic malesterilityin cultivated riceOryza sativa L. II: Theinheritance of malesterility.Jpn J Genet 44: 149-56

Shinjyo C. 1972. Distributions of male sterility-inducing cytoplasm and fertilityrestoring genes in rice I: Commercial lowland-rice cultivated in Japan.Jpn J Genet 47: 237-43

SiddiqEA, PJ Jachuck, M Mahadevappa, FU Zama, RVijayaKumar, BVidyachandraetal. 1994. Hybrid riceresearch in India. In:Virmani SS(ed), Hybrid ricetechnology: New developmentsand futureprospects[Selected papersfrom thelnternational Rice Research Conference]. Manila:IRRI. p 157-71

Siddiq EA. 1996. Currentstatusand futureoutlook for hybrid ricetechnology in India. In: Ahmed MI, BC Viraktamath, MSRamesha and CHM Vijaya Kumar (eds), Hybrid ricetechnology. Hyderabad:ICAR, Directorateof Rice Research p 1-27

Sohu VS and PS Phul. 1995. Inheritance of fertility restoration of three sources of cytoplasmic malesterility in rice. J Genet Breed 49: 93-6

Suprihatno B, BSutaryo and TSSilitohnga. 1994. Hybrid riceresearch in Indonesia. In Virmani SS(ed), Hybrid ricetechnology: New developmentsand futureprospects [Selected papersfrom the International Rice Research Conference]. Manila: IRRI. p 195-206

Upadhyaya HK. 1996. Rice research in Nepal: Current stateand future priorities. In: Evenson RE, RWHerdtand M Hossain (eds), Riceresearch in Asia:Progressand priorities. Manila:IRRI. p 193-215

Virmani SS and IB Edwards. 1983. Current status and future prospects for breeding hybrid riceand wheat. Adv Agron 36: 145-214

Virmani SS, BCVirakamath, CL Laral, RSToledo, MT LopezandJOManalo. 1997. Hybrid ricebreedingmanual. Manila:IRRI.151p

Virmani SS, RC Chaudharyand GSKhush. 1981. Currentoutlook on hybrid rice. Oryza 18: $67-84$

Virmani SS. 1994. Prospects of hybrid ricein thetropicsand subtropics. In:Virmani SS (ed), Hybrid ricetechnology: New developmentsand futureprospects[Selected papersfrom thelnternational RiceResearch Conference]. Manila:IRRI. p 7-19

Virmani SS. 1996. Hybrid rice. Adv Agron 57: 328-462

YoungJB, SSVirmani and GSKhush. 1983. Cyto-genic relationship amongcytoplasmicgenetic male sterile, maintainer and restorer lines of rice. Philip J Crop Sci 8: $119-24$

Yuan LP, ZYYangand JBYang. 1994. Hybrid ricein China. In:Virmani SS(ed), Hybrid rice technology: New developmentand futureprospects. Mania:IRRI. p 143-7

\section{Acknowledgements}

The Department of Botany, IAAS, Nepal provided laboratory facilities for pollen analysis. 